\title{
Forest bioeconomy - a new scope for sustainability indicators
}

Bernhard Wolfslehner, Stefanie Linser, Helga Pülzl, Annemarie Bastrup-Birk, Andrea Camia and Marco Marchetti 


\section{Contents}

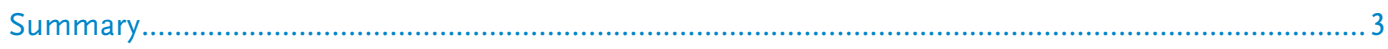

1. Using the full potential of forest indicators in a bioeconomy ........................................................... 5

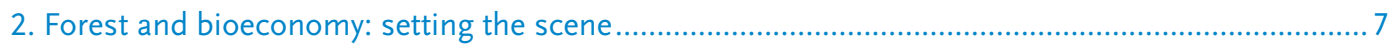

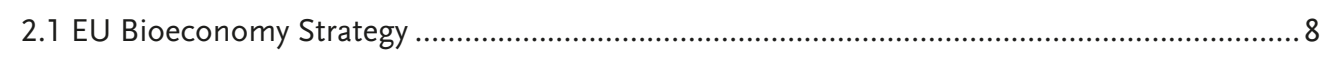

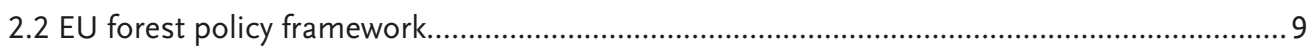

3. Indicators for sustainable forest management: what have we learned? ....................................... 10

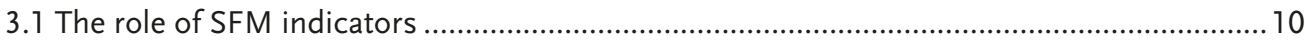

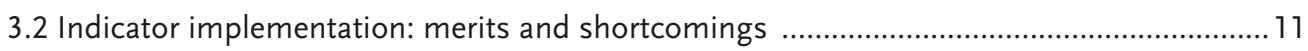

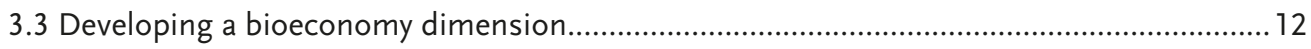

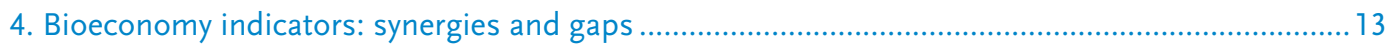

4.1 Current SFM indicators in the forest-based sector value chain ......................................... 13

4.2 Forest bioeconomy indicators - desert or Eldorado? ........................................................ 14

5. Measuring and assessing a forest-based bioeconomy ................................................................ 16

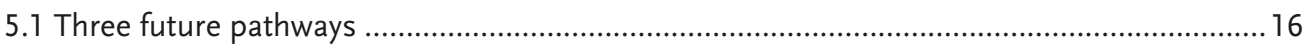

5.2 How to develop indicators - a matter of smart design ........................................................ 19

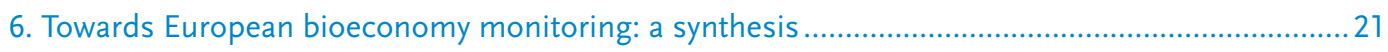

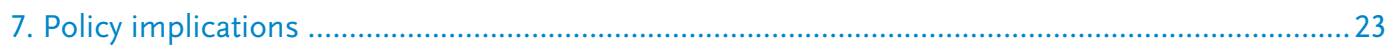

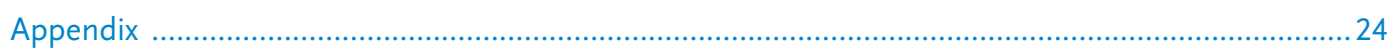

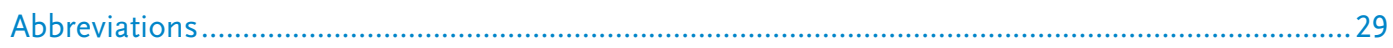

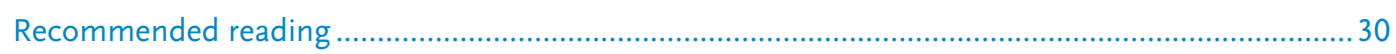

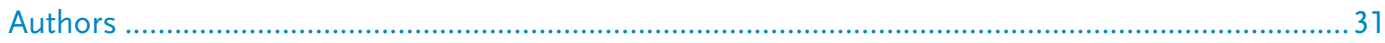

ISSN 2343-1229 (print)

ISSN 2343-1237 (online)

ISBN 978-952-5980-29-5 (print)

ISBN 978-952-5980-30-1 (online)

Editor in chief: Lauri Hetemäki

Managing editors: Rach Colling, Minna Korhonen

Layout: Grano Oy / Jouni Halonen

Printing: Grano Oy

Disclaimer: The views expressed in this publication are those of the authors and do not necessarily represent those of the European Forest Institute.

Recommended citation: Bernhard Wolfslehner,

Stefanie Linser, Helga Pülzl, Annemarie Bastrup-Birk,

Andrea Camia and Marco Marchetti. 2016. Forest bioeconomy

- a new scope for sustainability indicators. From Science to

Policy 4. European Forest Institute. https://doi.org/10.36333/

fs04 


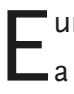
uropean forests and the forest-based sector play a central role in a bioeconomy: they provide material (wood and non-wood), bioenergy and a wealth of other regulating and cultural ecosystem services. These demands need to be properly balanced, and many targets have to be tackled simultaneously. How is wood grown and used? What are the economically, environmentally and socially sustainable production processes, products and services? How are non-wood goods and ecosystem services managed and valued? Where and how are forests and biodiversity protected, and how is this integrated into dynamic land use in Europe?

Ensuring sustainable development is a necessary precondition for a successful forest-based bioeconomy. There is a need for a realistic understanding of the potential capacity of forest resources to contribute sustainably. In a situation with many possibilities, synergies, trade-offs and uncertainties, indicators can help to avoid unwanted impacts, and support successful and sustainable bioeconomy development. They can be used to inform policy makers, synthesize complex matters and act as tools for decision support.

At present, there is a fragmented landscape of bioeconomy-related data and monitoring instruments. Current indicators for the forest-based sector have - reasonably - focused very much on the resource side: forests and their management, and have achieved considerable impact. However, to fully understand the implications of an increasingly diversified forest-based bioeconomy that differs in many ways from the past, a broader approach is needed. In the $20^{\text {th }}$ century, the forest sector was very much focused on pulp and paper products, wood products, and forestry related to these. Today, and increasingly so in the future, the forest-based bioeconomy is also bioenergy, biochemicals, textiles, construction, etc.

The forest-based sector has the opportunity to take the lead in the sustainable development of the bioeconomy. It has powerful tools in place that can be adapted and further developed for application in the bioeconomy as a whole. These tools have to be state-of-the art and continuously developed: here the forest sector can be a forerunner and role model, shaping the bioeconomy debate and its monitoring and assessment.

This study provides insights into the potential use of forest-based sector indicator sets in Europe. It builds on the rich experience gained with sectoral indicator tools, and connects to aspects of policy research, operational research and sustainability science. It develops three different options or scenarios for how bioeconomy indicators can be designed in the future.

\section{Policy implications}

- Indicators need to better capture the possible synergies and trade-offs between the different societal demands for forest resources, and between the forest sector and other sectors. They need to be responsive to new developments in the environment, society, and economy, and connect information on past and current states with prospective, forward-looking elements. Foresight and impact assessment tools are state-of-the-art methods that could be employed in a common bioeconomy indicator framework in this respect.

- Because of the diversification of the forest-based sector there is also a need to develop the collection and recording of the statistics that form the basis of the indicators, to more accurately reflect changes. Forest monitoring would benefit from being harmonised and its instruments made comparable with other sectoral instruments. The EU Bioeconomy Observatory/Bioeconomy Knowledge Centre initiatives could help to streamline data collection, assessment and interpretation of the impacts of the bioeconomy in the future.

- Forest-related policies are fragmented across sectors. The bioeconomy, as an umbrella concept, has the opportunity to raise forest-based issues to a new level, not segregated from other sectors' 
activities. Forest indicators are proven tools for monitoring the sustainability of forestry activities, but there is evidence that the sustainability impacts of forestry and forest products are not fully recognised outside the sector. The experience and lessons learned from forest indicator development and processes (e.g., FOREST EUROPE) should be made use of, and these indicators further updated and developed to fit the whole forest-based bioeconomy.

- Indicator development is often more a political than a technical task. Frequently, the strongest effort is put into technical design and data collection, while the negotiation of principles and goals is neglected. A cross-sectoral political forum could debate the priorities, metrics of assessment, choice of targets and the acceptance of trade-offs. With the EU Bioeconomy Panel and the European Bioeconomy Alliance there are already fora which enable cross-sectoral dialogue and cooperation.

- It is important to consider national strategies and approaches, and their role in the EU bioeconomy as a whole. Bioeconomy indicators have to feed into the discussion and planning of appropriate land use in Europe, the optimal use of our resources, and an awareness of possible leakage effects of European policies into the rest of the world (e.g., biomass imports). However, it should be acknowledged that EU Member States' forests and their forest sectors differ greatly, and a novel monitoring process should be a supporting instrument rather than an imperative.
- Indicators have so far been mainly used on a technical and administrational level. However, indicators could be used to communicate and provide information to the wider public, as well as supporting new forms of information-sharing and citizen science. New approaches such as key and headline indicators and indices should be tested to satisfy these needs.

- Indicators form the structural and methodological backbone of integrated bioeconomy monitoring. A common platform for the EU data providers and national data gatherers requires consensus and agreement on procedures, goals and targets. 


\section{Using the full potential of forest indicators in a bioeconomy}

The bioeconomy is expected to be the guiding paradigm within the forest-based sector in the years to come. It has been defined in various ways, and in a forest-based context can be understood to mean the utilisation of forests to create products and services that help economies to replace fossil-based raw materials, products and services. The forest-based bioeconomy links the whole forest value chain from the management and use of natural resources to the delivery of products and services.

Bioeconomy development increases the interest in forest resources from many sides. First, bioeconomy increases the demand for forest goods and services, and therefore also increases economic opportunities for the sector. This list of opportunities is long, including bioenergy, wood construction, packaging products, chemicals, textiles, etc. Second, there are growing requests for forest land for other ecosystem services, e.g., for biodiversity, carbon sequestration, recreation and effects on human health.

To realise these opportunities, they need to be carried out in a sustainable way - in all the dimensions of sustainability. The importance of this precondition becomes clear when looking back to the lessons learned from first-generation biofuels development in the beginning of this century. There was first a great hype for the opportunities these biofuels would create in helping to replace fossil-based fuels. Many new investments were made and new production processes started. However, after several years it became evident that these were not necessarily environmentally, economically or socially sustainable. These first-generation biofuels generated more $\mathrm{CO}_{2}$ emissions than they helped to mitigate, they were not necessarily economically viable, and they caused problems for the food sector by using agricultural land for biofuel production. As a result, after the hype came the hangover. First-generation biofuels production got a bad name in society, lost government and public support and has gradually been declining.

The lesson learned is that sustainable development is a necessary precondition for a forest-based bioeconomy. It is also a precondition for winning support from society at large. Consequently, there is a need for a realistic understanding of the potential capacity of forest resources to contribute sustainably to a bioeconomy. Sustainable development needs to be at the heart of the bioeconomy concept, and has to take account of local and regional conditions.

History also shows that sustainability is not a mechanism that markets would regulate automatically. In order to succeed, the sustainability of bioeconomy development needs to be monitored and assessed. By doing so, unwanted outcomes can be avoided, and the success of forest-based bioeconomy development secured.

The diversification of the forest-based bioeconomy is also a key issue. In the $20^{\text {th }}$ century, the forest-based bioeconomy was very much focused on pulp and paper products, wood products, and forestry related to these. Today, and increasingly so in the future, the forest-based bioeconomy is also bioenergy, biochemicals, textiles, construction, etc. The statistics and old indicators measuring economic and social sustainable development in the forest-based sector are lagging behind actual development, thus giving inaccurate information about its economic and social significance. It is also essential for new advances (sectors) to follow the environmentally sustainable practices already incorporated in "traditional" forest-based sectors.

We need to review and update how we monitor and assess the sustainable development of this increasingly diversified forest-based bioeconomy, that differs in many ways from the past. Successful bioeconomy development will also depend on having meaningful indicators and monitoring for the widening forest-based sector. In a situation with many possibilities, synergies, trade-offs and uncertainties, indicators can help to assess and inform about desired sustainable development paths, and can become a useful tool for policy making and natural resource planning.

In a forest-related bioeconomy many targets have to be tackled. How is wood grown and used? What are the economically, environmentally and socially sustainable production processes, products and services? How are non-wood goods and ecosystem services managed and valued? Where and how are forests and biodiversity protected, and how is 
this integrated into dynamic land use in Europe? Existing sustainable forest management initiatives already have a lot to offer to help answer these questions.

The forest-based sector has the opportunity to take the lead in the sustainable development of the bioeconomy. It has powerful tools in place that can be adapted and further developed for application in the bioeconomy as a whole. Indicators can inform policy makers, synthesize complex matters and act as tools for decision support. These tools have to be state-of-the art and continuously developed: here the forest sector can be a forerunner and role model, shaping the bioeconomy debate and its monitoring and assessment.

This study provides insights into the potential use of forest-based sector indicator sets in Europe. It builds on the rich experience gained with sectoral indicator tools, and connects to aspects of policy research, operational research and sustainability science. The study develops:
- options for updating indicators to better fit with changing sector developments and to help guide towards achieving bioeconomy policy objectives;

- ways to broaden current forest indicators to include diverse forest-based value chains of products and ecosystem services;

- synergies and potentials for streamlining data and information management.

The study applies a value chain approach for indicators, that encompasses the life cycle from primary production to recycling, and discusses structural and institutional requirements. It starts from a notion that existing forest criteria and indicators for sustainable development are a strong asset, and further developments should build on these merits. Finally, it provides policy implications to inform how monitoring and indicators could help to secure sustainable bioeconomy development in the future. 


\section{Forest and bioeconomy: setting the scene}

In this study, we follow the bioeconomy definition in the EU Bioeconomy Strategy. According to this, the bioeconomy is a more innovative and low-emissions economy, reconciling demands for sustainable agriculture and fisheries, food security, and the sustainable use of renewable biological resources for industrial purposes, while ensuring biodiversity and environmental protection. Although the concept has a technological origin, it strongly appeals to the forest-based sector, which consists of all the industrial activities that use forest biomass in general. However, it is important to also acknowledge the limitations of this definition. In particular, it does not include the services related to forests and the forest sector, which are likely to be very important.

In a bioeconomy context, an important challenge for the forest-based sector is to overcome the narrow definition of forest resources and wood-based products, including primary production. There is a need to move towards a horizontally and vertically integrated sector which covers the whole value chain of forest products and services, taking sustainable development as its core principle. Moreover, in a world in which narratives are ever more important, fact- and science-based narratives can be important to inform policy makers and the public at large. It is important for the forest-based sector to demonstrate its contribution to a bioeconomy in a sustainable and inclusive way.

How to measure, monitor and assess forest bioeconomy developments lies at the core of this study. For guidance on where indicators for a sustainable forest bioeconomy should head for, a clear understanding of its underlying principles and goals is needed. In the context of an EU bioeconomy, there are particular opportunities for further developing forest-related indicators that:

- address the opportunities and challenges voiced by the EU Bioeconomy Strategy;

- define inter-sectoral tools that seek compliance with other sectors and initiatives;

- strengthen assessment features to estimate the sustainability impacts of moving towards a bioeconomy.

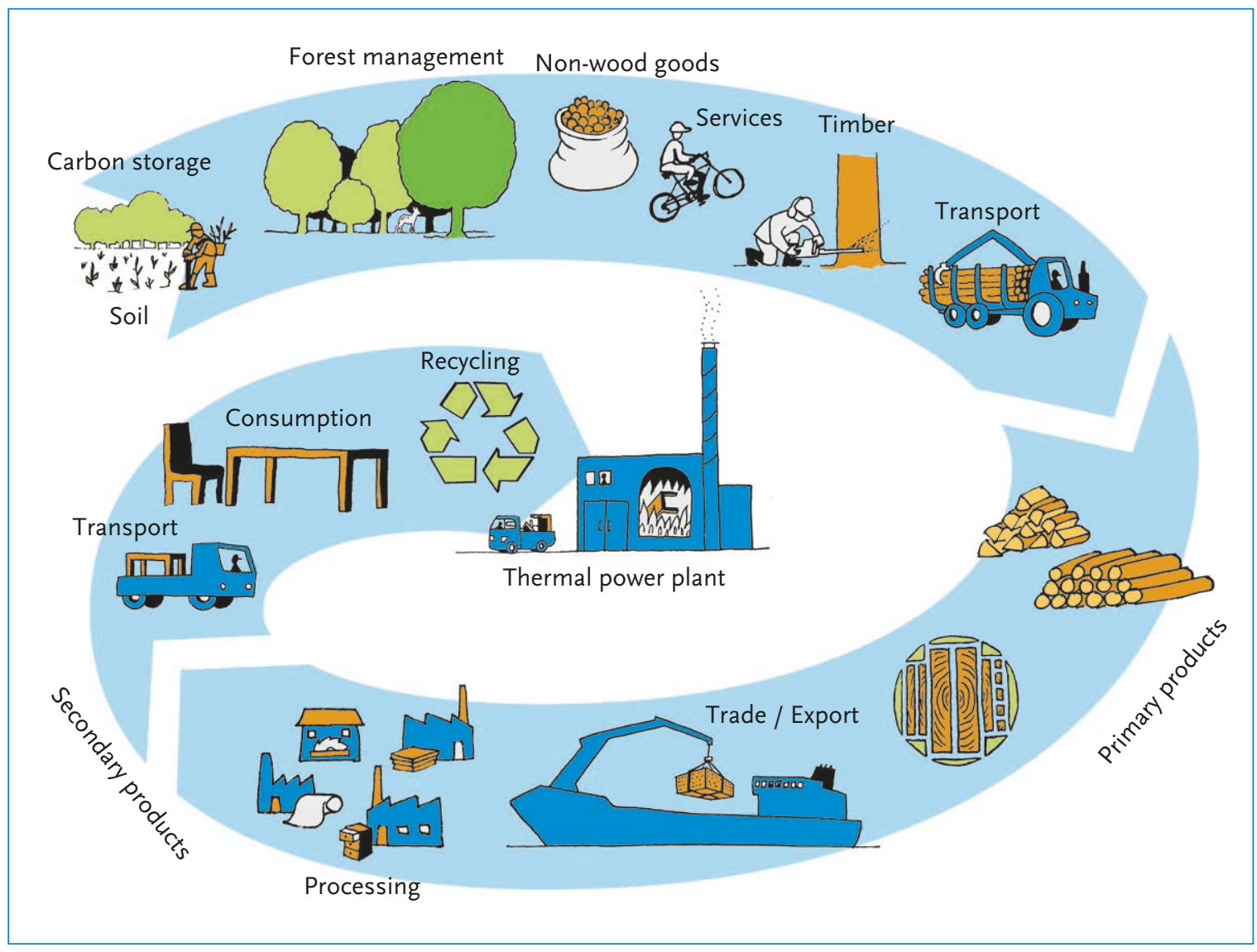

Figure 1. Example of a forest-based sector value chain. 


\subsection{EU Bioeconomy Strategy}

Under the bioeconomy objectives, the EU Bioeconomy Strategy has five main societal challenges which offer great potential and challenges for the forest-based sector, while not explicitly referring to it.

Ensuring food security: Food security links to the question of land use, land use change, and intensity of land use both in Europe and worldwide. For forestry, a potential intensification of forest resource use, a stronger segregation of use and non-use of forests, competition between land-use forms, and (global) displacement effects due to increased demand for natural resource are to be explored.

Managing natural resources sustainably: This refers to the core business of the forest-based sector, and relevant activities in defining and evaluating sustainable forest management over the past 25 years. A long-term surplus of increments and increasing growing stock of wood in Europe has led to calls for stronger wood mobilisation and the potential for intensified resource use. However, non-industrial forest ecosystem services and social impacts must not be abandoned in a bioeconomy context, which is currently very biomass-centred in many policy processes.
Reducing dependence on non-renewable resources: The use of forest biomass for energy and forest products and phasing out fossil-based raw materials and products can make economic and environmental sense if accompanied by a package of measures to promote best practices in forest management. Clearly, earlier experiences with first generation biofuels indicate the need for care, and environmentally and economically efficient processes. Best practices should also consider the diversity of forest types and management systems across Europe, ensure biodiversity safeguards and aim to balance all forest functions.

Mitigating and adapting to climate change: This is a key concern for the forest-based sector in particular, with regard to the resilience of forests against climate change effects, and the role of forests and forest products in contributing to a low-carbon society. The possible trade-offs between carbon sequestration and stronger resource use have to be balanced. Given consistent incentives, forests and the forest sector can make an important contribution to climate change mitigation while also serving other bioeconomy objectives.

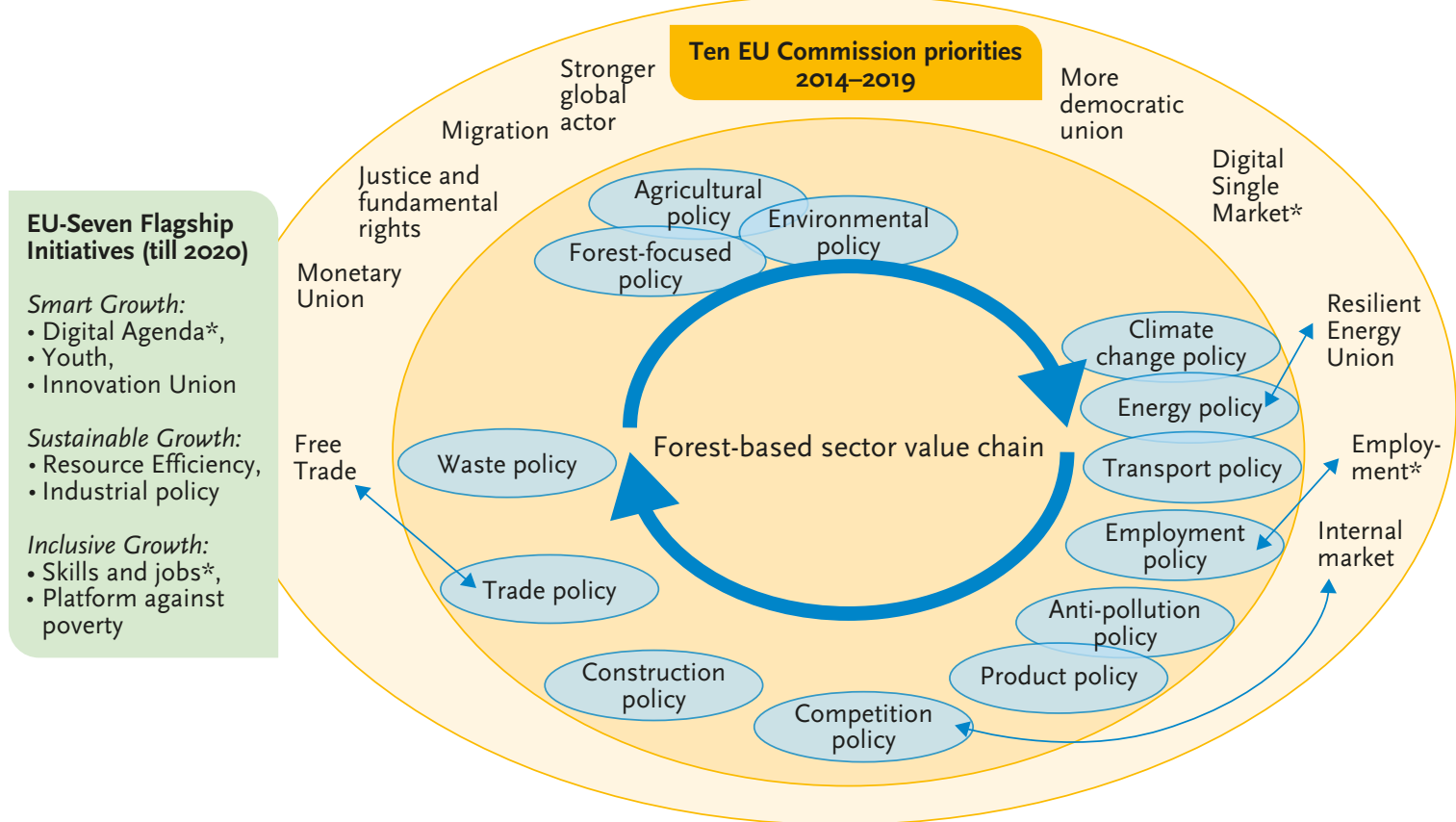

Figure 2. The EU's main policy priorities and EU forest-related policies. Stars (*) refer to topics that are addressed in both the EU flagship initiatives and the new 10 European Commission priorities. 
Creating jobs and increasing European competitiveness: The forest-based sector has recently fallen under substantial pressure due to the economic crisis, globalised production and societal changes such as digitalisation. In the bioeconomy, the diversification of the sector towards bio-based industries and services is providing new opportunities for innovations, products, services, markets and jobs.

\subsection{EU forest policy framework}

Monitoring forest bioeconomy development in the EU is complex, because it builds on a fragmented policy framework. To understand the role of forest-related topics and policies in a bioeconomy, it is important to understand the supranational EU forest policy framework currently in place. It is also necessary to analyse current policy objectives and their relationship with the bioeconomy, and the larger EU context within which a bioeconomy is embedded.

By 2020 , the EU has five main policy targets:

- employment (75\% employed in the EU);

- poverty (20 million fewer people at risk of poverty);

- climate change and energy sustainability (20\% greenhouse gas emissions reduction, $20 \%$ energy from renewables, $20 \%$ increase in energy efficiency);

- research and development ( $3 \%$ of the EU's GDP);

- education (decrease rate of early school leavers to below I0\% and reach 40\% third-level education).
Seven flagship initiatives have been formulated. However, when a new European Commission was appointed in 20I4, additional priorities were defined (Figure 2). In the meantime, additional and more ambitious targets have been published which already reach beyond 2020: e.g., climate and energy policies (2030), halting illegal logging (2030) and cohesion policy (2050).

The EU forest-related policy framework has to be seen against this background. There is no common EU forest policy, but rather two non-legally binding documents (EU Forest Strategy and the multi-annual implementation plan of the EU forest-related policy) which provide the main framework for forest action in the EU. Other EU legislative acts and policies likely to affect forests correspond to a complex system of policy instruments. While completely covering this list is beyond the scope of this study, a number of policy areas which have an impact on the contribution of forests and the forest-based sector to a bioeconomy may be identified (see Appendix, Table I). These policies should give guidance for a comprehensive bioeconomy indicator set.

It should be kept in mind, however, that only the EU strategies, action plans, directives and regulations that relate to the forest-based sector have been analysed. Since some of the policy areas are a shared competence of the EU and its Member States, the latter also have a much larger number of policies in place that are deemed relevant in a bioeconomy context. Those cannot be tackled in this study. 


\section{Indicators for sustainable forest management: what have we learned?}

Indicators are on the political agenda of a variety of national, regional and global policy processes. They are part of core discussions of sectoral processes and proposed EU assessment approaches, such as sustainability criteria for bioenergy, European core health indicators and European tourism indicators. Over the past 25 years, indicators have also become prominent in evaluating sustainable forest management, and have been used by both political processes and certification initiatives, and for the new EU Forest Strategy. They are also a central element of the framework for assessing the implementation of the UN Sustainable Development Goals (SDGs) in the future.

Indicators are the tools of choice for measuring, monitoring, and assessing sustainability progress. Sustainable forest management (SFM) indicators have so far been used for monitoring and reporting, for communicating information to a wider audience, for policy formulation in national forest programmes, and to a certain extent for performance assessment. The Pan-European Indicators for Sustainable Forest Management developed by FOREST EUROPE have been referred to in many political debates, and have proved useful for forest monitoring and reporting both at national and European level. These forest-related indicators have great potential to become functional instruments for a knowledge-based forest bioeconomy. However, it is necessary to analyse what indicators would be needed, and could be applied to monitor and assess the state and progress of the forest-based sector's contribution to the bioeconomy.

\subsection{The role of SFM indicators}

FOREST EUROPE is the pan-European forest policy process for the continent's forests, joining efforts with UNECE and the FAO Forest Resource Assessment (FRA). Through the FOREST EUROPE process, 46 member states and the EU aim to develop policies on how to protect and sustainably manage forests. This process has also developed a pan-European criteria and indicators (C\&I) set for sustainable forest management: 6 criteria and 34 quantitative indicators describing the forest status and changes, and II qualitative indicators describing national forest policies, institutions and instruments towards SFM. The pan-European set has served as the basis for the State of Europe's Forests assessments in 1998, 2003, 2007, 201I, 2015 and has provided the basis for regional and national policy formulation, its analysis and monitoring efforts.

In addition, there are many other regional forest policy processes and initiatives, such as the Montréal Process. International organisations such as the International Tropical Timber Organisation (ITTO) and certification processes (e.g., FSC, PEFC) employ indicators as well. Parallel to the work carried out in the forestry sector, indicators have been developed and used by many other sectors and organisations. For instance, the OECD, the UN Commission on Sustainable Development and Eurostat monitor sustainable development; the Convention on Biological Diversity and the European Environment Agency monitor and assess biodiversity conservation. On a global level, UNECE and FAO have developed indicators as a basis for regular and harmonised Forest Resource Assessments. In the light of the recently developed UN Sustainable Development Goals (SDGs), indicators will be an essential element in monitoring global progress. Forest resources will however play a rather subordinated role.

Overall, there are two main areas of use and application for SFM indicators: the collection and presentation of condensed and comparable information, and consequently the use of this information by decision-makers for policy making and monitoring.

Forest-related indicators have been developed at different levels of governance. FOREST EUROPE indicators helped to operationalise sustainable forest management along the lines of criteria - essential elements or conditions by which SFM may be assessed. Indicators nowadays are mainly used for international and pan-European reporting purposes to monitor forest resources and the sustainable management of forests, and also feed into practical certification instruments. This set-up demands national implementation, hence national and local indicator sets have been derived.

More recently, indicators have gained attention in sustainability impact assessment, to progress from 
a sheer reporting exercise towards an impact assessment of sustainable forest management. Recent advances in sustainability science propose a 'nested' sustainability concept that integrates the ecosystem services concept with sustainable development. While there has been considerable progress in science, such as the impact assessment of bioenergy or forest value chains, this has not carried over to decision-making in the forest-based sector.

\subsection{Indicator implementation: merits and shortcomings}

While the demand for forest-related indicators as data carriers is potentially large, there are certain areas where indicators have been particularly applied. A recent European Forest Institute (EFI) study identified five major applications of indicator use in Europe:

- Reference framework for dialogue, communication, and streamlining the forestry debate.

- Tool for monitoring and reporting on the progress towards sustainable forest management, and improving quality and comparability of forest information among European countries.

- Reference framework for the development and adaptation of national policy instruments and/or forest-related policies.

- Assessment tool for measuring progress towards sustainable forest management and identifying emerging issues.

- Information tool for creating links to other sectors and global initiatives.

Forest indicators have contributed to:

- agreeing to shared definitions, e.g., finding a common understanding of what constitutes sustainable forest management;

- shaping monitoring and reporting activities;

- facilitating unambiguous communication and learning efforts among stakeholders;

- fostering education and capacity-building through participatory decision-making and decentralized policy implementation;

- supporting participatory modes of decision-making, knowledge generation and exchange that grant active actor involvement, inclusiveness of interest and bottom-up initiatives;

- reaching a global convergence for indicator implementation.
In the context of the bioeconomy, it is clear that there is a solid basis of experience regarding indicator use and implementation within the forest-based sector. However, these indicators have not been specifically designed to cover the whole value chain, a pre-requisite for demonstrating better the contribution of the sector in a bioeconomy.

There are also downsides to the successes achieved. Activities have remained within the forest sector, and found little resonance outside. Recent research indicates that there are feasible approaches to incorporate LULUCF considerations in indicator frameworks, for example. Moreover, the key feature of forest-based bioeconomy development is the $\mathrm{di}$ versification of the sector. In the $20^{\text {th }}$ century, the forest sector was very much dominated by the pulp and paper industry and wood products industry, and forestry activities related to these. However, in the $2 \mathrm{I}^{\text {st }}$ century the major trend is the diversification of the forest-based sector to energy, chemicals, textiles, etc. It is clear that monitoring and indicators have to be able to reflect this diversification and the new reality. To make indicators fit for the bioeconomy and exploit their full potential, overcoming these sectoral boundaries will be essential. A new approach also provides the opportunity to remove some frequently observed obstacles and difficulties, such as:

- too narrow focus on only the resource side, neglecting the market, technologies and whole forest-based value chain perspective;

- missing a conceptual framework to explain the causal relationships of resource use and impacts;

- unclear references to political goals and objectives;

- limited operational design and data availability;

- lack of assessment features which provide diagnosis, warning signals and guidance;

- unbalanced indicator sets, that are often weak in terms of socio-economic aspects;

- weak harmonisation as regards forest information terms and definitions, which hampers reliable indicator interpretation.

To define a reliable and fit-for-purpose set of forest-related bioeconomy indicators, all these concerns have to be taken into account. This includes the changing boundaries of the sector, as well as conceptual, technical and procedural aspects. It is also important that future indicator sets are comparable and congruent. Global frameworks such as the SDGs should also be taken into account in a bioeconomy set-up. 


\subsection{Developing a bioeconomy dimension}

When considering the five major challenges defined in the EU Bioeconomy Strategy, substantial cross-references to the forest-based sector can be identified which will require investigation and measurement (Table 2). An analysis of the EU Bioeconomy Strategy text identified the forest-relevant topics, and gives guidance on the topics to be addressed by indicators. It shows that classical SFM indicators can cover a significant range of issues, but will need to be complemented by indicators along the value chain ranging from biomass to other ecosystem services.

It is important to guarantee that indicators address these topics in a balanced way, are applicable at different spatial and administrative scales and are sensitive to changes both in time and economic, social and ecological dynamics.

Table 2. Forest-related topics in the EU Bioeconomy Strategy.

\begin{tabular}{|c|c|}
\hline Bioeconomy criteria & Forest-related topics \\
\hline \multirow[t]{3}{*}{ Ensuring food security } & $\begin{array}{l}\text { Role of forests in watershed management and the provision of water for agriculture } \\
\text { and fisheries to secure sustainable food production }\end{array}$ \\
\hline & Edible non-wood forest products \\
\hline & Forage and feed for livestock \\
\hline \multirow{6}{*}{$\begin{array}{l}\text { Managing natural resources } \\
\text { sustainably }\end{array}$} & Using existing SFM criteria and indicators for SFM \\
\hline & Forest ecosystem services \\
\hline & Social services like health/wellbeing \\
\hline & Desertification \\
\hline & Illegal logging \\
\hline & Green infrastructure \\
\hline \multirow{6}{*}{$\begin{array}{l}\text { Reducing dependence on } \\
\text { non-renewable resources }\end{array}$} & Low carbon society: carbon sequestration, carbon footprint, carbon neutrality \\
\hline & $\begin{array}{l}\text { Renewable goods and substitution of fossil products: bio-based products, bioener- } \\
\text { gy, carbon in wood products }\end{array}$ \\
\hline & Resource efficiency \\
\hline & Biomass availability \\
\hline & Energy security, independence from non-renewables \\
\hline & Indirect land use change, displacement effects of EU biomass demand \\
\hline \multirow{5}{*}{$\begin{array}{l}\text { Mitigating and adapting to } \\
\text { climate change }\end{array}$} & Compliance with climate protocol \\
\hline & Resource efficiency \\
\hline & Carbon accounting \\
\hline & Climate change effects: diseases, pests, fires \\
\hline & Resilience and risk \\
\hline \multirow{6}{*}{$\begin{array}{l}\text { Increasing competitiveness } \\
\text { and creating jobs }\end{array}$} & Jobs in rural and in urban areas \\
\hline & Forest sector workforce \\
\hline & Green jobs, services to/from the sector \\
\hline & Innovation and start ups \\
\hline & Diversification of forest-related bio-based products \\
\hline & Emerging societal trends and new markets \\
\hline
\end{tabular}




\section{Bioeconomy indicators: synergies and gaps}

\subsection{Current SFM indicators in the forest-based sector value chain}

Analysis of current forest indicators as implemented by FOREST EUROPE (strongly in line with other indicator initiatives worldwide), shows there is a strong focus on the early stages of the forest-based value chain, i.e., forest resources and primary production. The pan-European indicators (34) for SFM cover mostly the first part of the forest-based sector value chain, with three exceptions: wood consumption, trade in wood, and energy from wood resources (Figure 3).
This forestry-centred indicator set creates a valuable core when talking about the sustainability of forestry production, but it has been designed for a different purpose: safeguarding the sustainable management of forests.

The whole forest-based value chain is very much linked to a bioeconomy. It does not only concern the primary production of forest resources, but also the use of wood and non-wood material, the provision of forest ecosystem services, as well as energy production and material use during recycling processes. Therefore, a broadening of current forest indicator understanding is required.

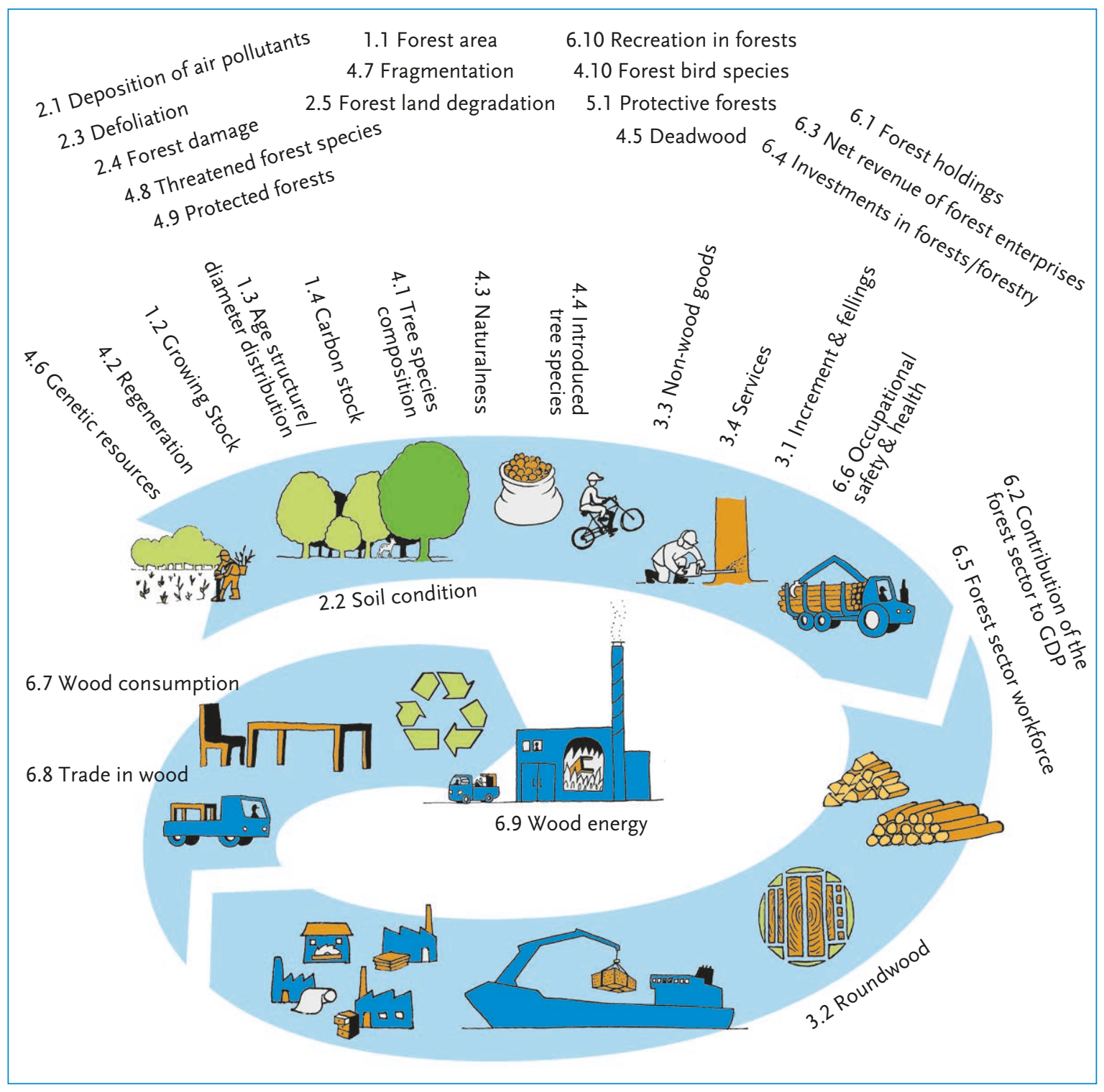

Figure 3. Current pan-European indicators for sustainable forest management. 
There are many aspects that are currently not sufficiently addressed by existing indicators. Indeed, a variety of topics could be added to the analysis to get a more comprehensive picture. According to recent analysis, relevant indicator gaps along the forest-based value chain relate to topics such as:

Table 3. Indicator gaps along the forest-based value chain.

\begin{tabular}{|c|c|}
\hline Topic & Indicator gap \\
\hline \multirow[t]{6}{*}{ Forest management } & Forest ecosystem services \\
\hline & Social services regarding health and wellbeing \\
\hline & Illegal logging \\
\hline & Certification \\
\hline & Carbon storage in wood products \\
\hline & Carbon footprint \\
\hline \multirow{11}{*}{$\begin{array}{l}\text { Forest-based sector and } \\
\text { secondary production }\end{array}$} & Environmentally sound processing \\
\hline & Innovation in processes and products \\
\hline & New markets \\
\hline & Diversification of forest-related products \\
\hline & Secondary or value-added forest products \\
\hline & Bioenergy, biorefineries \\
\hline & Forage and feed for livestock \\
\hline & Green jobs \\
\hline & Sustainable construction \\
\hline & Recycling \\
\hline & Green public procurement \\
\hline \multirow[t]{3}{*}{ Logistics } & Sustainable transport from the forest road to the factory \\
\hline & Sustainable transport from the factory to the consumer \\
\hline & Green infrastructure \\
\hline
\end{tabular}

This gives a clear indication that existing forest-related indicators can be broadened and enhanced. When a more advanced approach along the value chain is taken, stronger cross-sectoral demands for implementable indicators appear. These should build strong ties to increasingly diversified forest-based products and markets (wood products, pulp and paper, packaging, chemicals, textiles, biomass etc.), and the broader public interest in forest goods and services. Bioeconomy indicators relating to these, and how these markets are related to other sectors need to be developed.

\subsection{Forest bioeconomy indicators - desert or Eldorado?}

Moving towards a forest-based bioeconomy approach leads to the question: is there sufficient information available that has simply not been brought into a common context, or is there also a lack of available indicators and related data?

We analysed the available information in relation to bioeconomy and indicators, and assessed whether it related to existing SFM indicators and to the challenges identified by the EU Bioeconomy Strategy. Including indicators from outside the sector enables a response to the need to depict rapid changes in the forest-based sector such as outsourcing of workforce and services, which are currently not reflected in official statistics.

A richness of indicator-based approaches which can be linked to a forest-related bioeconomy, and which go beyond the classical understanding of SFM, were found. Potential indicators were detected in various workshop reports, scientific studies, 58 different databases and in existing operational indicator sets, mainly from outside the sector. The most valuable ones link to official statistics. 
A content analysis initially identified 203 potential indicators relevant for assessing a bioeconomy. This list was narrowed down using the following criteria:

- covered/not-covered by the 34 pan-European indicators for SFM;

- matching/not-matching related forest-relevant challenges of the EU Bioeconomy Strategy;

- adequate/not-adequate for assessing positive/ negative directions of change;

- data availability and quality (but not exclusively, to give room for new monitoring incentives).

This exercise led to the identification of 73 indicators. These indicators complement the substantially good coverage of the resource side by the existing FOREST EUROPE indicators; however, their operational strength is mixed. Data availability and quality differs considerably among them (see Appendix, Table 4).

As well as defining attributes to measure, it is important to analyse how they can be linked to measurable objectives (see Appendix for an indicator typology).

Analysis showed that most indicators are output and outcome indicators focusing on products, goods and services or on more general results. Few input, activity and process indicators were found, which would be needed to get a systemic insight into why things happen. Most indicators clearly focus on changes in societal and natural systems, but cannot explain the reasons or stages of impacts sufficiently. This would be needed for more inclusive methods along the value chain, such as Life Cycle Analysis. Two-thirds of the indicators are suitable for sustainability assessments, assuming that time-series data are available.

Beyond conceptual considerations of selecting indicators which capture the full dimension of a forest bioeconomy, data availability and the degree of operational usability are the main concerns for indicator sets and systems. Yet, data availability alone is not a knock-out criterion for choice. Such an approach would most likely lead to data availability bias in future bioeconomy assessment, and would exclude new emerging issues and trends. Around $50 \%$ of potential indicators currently suffer from insufficient data availability. A need for further data acquisition is obvious.

From this analysis, we conclude that there is a strong backbone of forest-related indicators and a range of potential indicators from other information and statistics sources. However, there are still some steps needed to create a consistent, coherent and systematic indicator set that demonstrates and assesses the contribution and performance of the forest-based sector in a bioeconomy. 


\section{Measuring and assessing a forest-based bioeconomy}

\subsection{Three future pathways}

Based on the analysis, it can be concluded that current indicators for sustainable forest management are very sectoral. Additional relevant information is scattered within very different sources, or is not specifically linked to forests, and in some cases does not exist. For consistent forest bioeconomy monitoring, an updated approach is required that can allow a pragmatic evolution from current sets to new, innovative solutions.

We suggest three options to improve the indicators and related monitoring for forest-based bioeconomy purposes:

Option r: Complement the current pan-European indicator set for SFM with additional bioeconomy themes and indicators

Option 2: Develop a new forest bioeconomy indicator set with thematic subsets of indicators

Option 3: Design a cross-sectoral key indicator set These options are not mutually exclusive, and could be applied in chronological order according to resourcing and identified needs.

Option 1: Complement the pan-European indicator set for SFM with additional bioeconomy-related topics

This option takes a pragmatic approach, recognising that around 25 years of investment and experience are gathered in the current pan-European indicator set for SFM. The set was updated in 20I5, and also confirmed by a working group of the European Commission as a reference for forest sustainability evaluation in the EU.

This can be used as a starting point to initiate a process where identified gaps along the forest-based value chain are successively closed by complementing the current indicator set with references to the bioeconomy and the respective EU forest-relevant policy framework. Figure 4 gives an indication of how this indicator set could be completed with new indicators along the entire value chain.

This approach has the advantage of building on a well-proven institutional framework and capacities (including national data collection). It thus implies a form of evolution rather than revolution. This solution also means that the long list of current indicators is expanded, which increases the efforts for data collection. It also requires a response to the shortcomings of current statistics, such as a redefinition of sectoral boundaries.

\section{Option 2: Develop a new forest bioeconomy in-} dicator set with thematic subsets of indicators This option implies a conceptually more advanced approach than Option I. It includes some of the pan-European indicators for SFM, but is intrinsically meant to be a process for developing new, additional indicators, following a new thinking. The central objective is no longer SFM, but is shifted towards the sustainability of the whole forest-based value chain, not just the forest management part.

The EU Bioeconomy Strategy provides the basis for the new indicator framework and relevant criteria for it. More specifically, in line with the five societal challenges of the EU Bioeconomy Strategy (see 2.I), five subsets of indicators should be developed (Figure 5). This approach will require more time and resources to set up a related cross-sectoral indicator process, but will be more tightly linked to the EU Bioeconomy Strategy. It offers the opportunity for sectoral harmonisation and synchronised methods of data and information management. This approach requires a cross-sectoral dialogue on the sub-topics which are part of a forest bioeconomy. It will create a new picture of business services and ecosystem services, which relate to the sector and beyond.

Option 3: Design a cross-sectoral key indicator set

This option is based on a new trend in indicator development and use, for example applied by Eurostat (Europe 2020 strategy headline indicators) and the European Environment Agency (Core set of indicators). It builds on a limited number of key, core or headline indicators which aim to deliver a short, understandable picture of sustainability aspects in a bioeconomy. This would allow communication to a broader audience, decrease data collection and reporting burdens, and support a concentrated discussion on what the key information needs for decision-making are.

This approach could run in parallel to, or be backed up by, larger sets which can be used to synthesise (sub)indicators or composite indicators (e.g., 


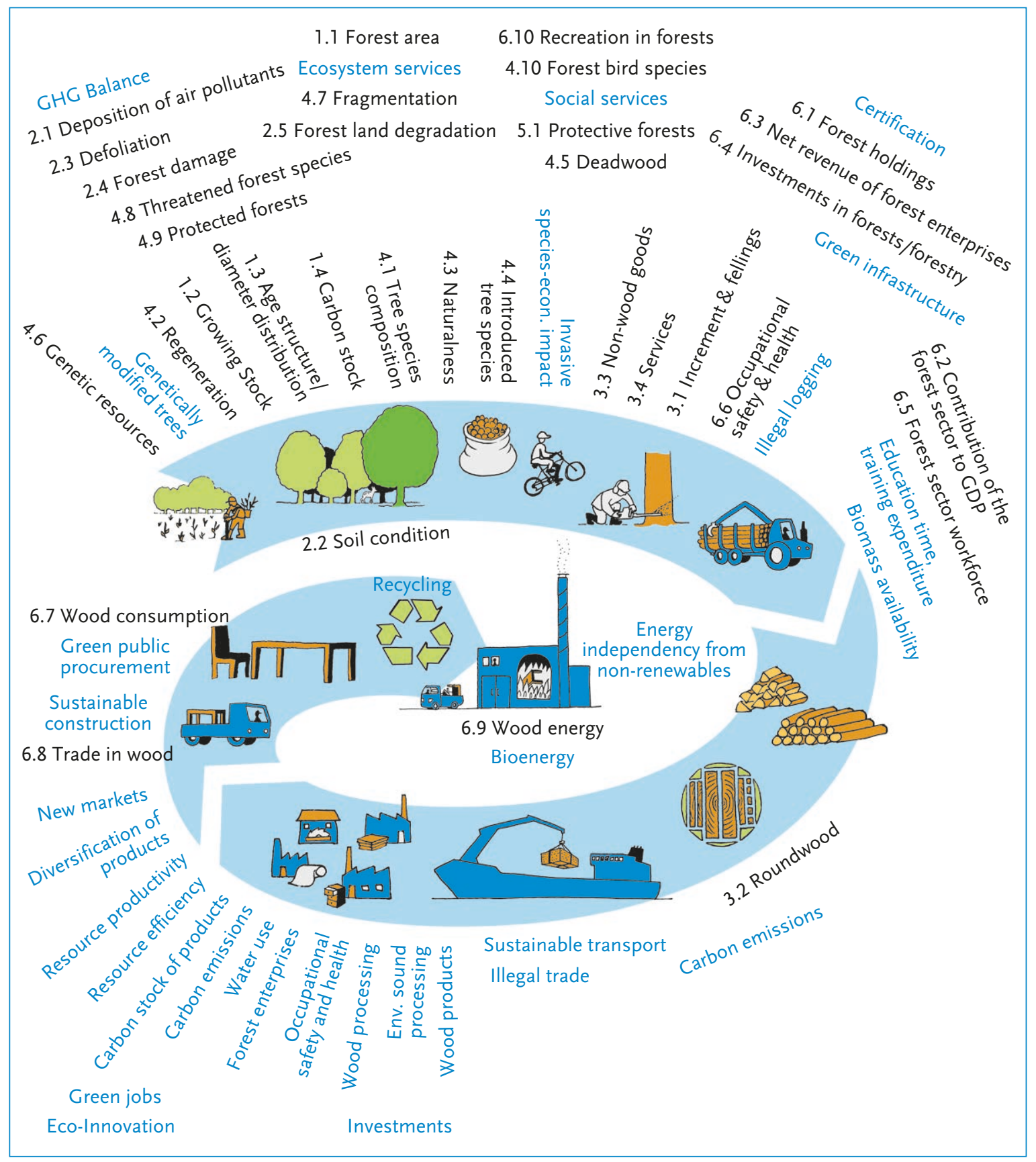

Figure 4. Current pan-European indicators for SFM and complementary additional indicators (in blue) along the forest-based sector value chain. 


\begin{tabular}{l} 
Sustainable resource management \\
Red List Index \\
\hline Natural Resource Index \\
\hline Forest area \\
\hline Forests under management plan \\
\hline Protected forests \\
\hline Threatened forest species \\
\hline Age structure and/or diameter distribution \\
\hline Increment and fellings \\
\hline Roundwood \\
\hline Growing stock \\
\hline Forest fragmentation \\
\hline Tree species composition \\
\hline Regeneration \\
\hline Naturalness \\
\hline Deadwood \\
\hline Common forest bird species \\
Value of marketed services on forest and other wooded \\
land \\
\hline Recreation in forests \\
Impacts on human wellbeing \\
\hline Urban forestry and human health \\
Trends in forest land degradation \\
Illegal logging and associated trade \\
Woody bioenergy feedstocks supplied in accordance \\
with EUTR \\
\hline
\end{tabular}

Independence of non-renewables

Carbon footprint

Resource productivity

Share of renewable energy in gross final energy consumption

Resource use of the bioeconomy

Indirect land use/ embodied land for agriculture and forestry products

Recycling rate for paper and wood products

Wood consumption

Raw material consumption

Production of goods and services in total FWC and by sub-sector

Use of wood in total FWC and by

sub-sector

Cascading use of biomass

Use of permanent materials

Trade in wood

Cost-competitiveness of biofuels compared with nonrenewable energy sources

Net energy balance

Wood energy
Climate change adaptation \& mitigation

GHG balance

Resource and materials efficiency

Forest-related carbon stocks

Forest damage

Deposition and concentration of air pollutants on forest and other wooded land

Defoliation

Soil condition

Introduced tree species

Economic impacts of invasive species

Genetic resources

Genetically modified trees

Protective forests

\section{Food security}

Blue water footprint of wood products

Water use in total FWC and by sub-sectors

Value and quantity of marketed non-wood goods from forest and other wooded land

\section{Competitiveness \& jobs}

Employment in the total bioeconomy and its sectors, and the contribution of the bioeconomy to total regional employment

Eco-innovation index

Forest holdings

Contribution of forest sector to GDP

Forest sector workforce

Education time in total FWC \& Training expenditure as $\%$ of turnover in total FWC

Quality of employment in total FWC

Occupational safety and health

Production \& employment in wood-working, manufacture of pulp, paper \& paper-board, converting, printing

Renewable energy jobs

Innovation - new products in total FWC and by subsector

Growth of specific bio-based technologies, processes or products

Use and development of biotechnology in the bioeconomy

Development of advanced biorefinery technologies for the production of energy and materials

Research into technical and organisational aspects of new bioeconomy initiatives

Development of environment-related technologies, $\%$ all technologies

Patents on resource efficiency technologies

Share of biofuel industry that is part of the bioeconomy in terms of GDP, employment, turnover

Share of chemical industry that is part of the bioeconomy in terms of GDP, employment, turnover

Figure 5. Subsets of indicators relating to a forest bioeconomy. 
a footprint). Such key indicators are ideally designed in a way which supports cross-sectoral application.

Recent experiences show that selection processes and the simplification of information are very demanding, both in terms of rigidity and acceptance of stakeholders. On the other hand, selection could build on Options I and 2, and the outcomes of other processes that employ key indicators. It could be seen as an evolutionary step, following a consolidation of bioeconomy indicators.

A core set of key or headline indicators for forest bioeconomy could include:

Table 5. Key indicators for forest bioeconomy.

\begin{tabular}{|l|}
\hline Resource use \\
\hline Resource productivity \\
\hline Resource and materials efficiency \\
\hline Water footprint \\
\hline Natural resources index \\
\hline Share of renewable energy in gross final energy consumption \\
\hline Indirect land use/embodied land for agriculture and forestry products \\
\hline Red List Index of threatened species \\
\hline Carbon footprint of the forest and harvested wood chain (carbon stock changes) \\
\hline Greenhouse gas balance (emissions and sequestration) \\
\hline Employment in forest-based bioeconomy sectors, and contribution to regional employment \\
\hline Eco-innovation index
\end{tabular}

While these indicators address key aspects of bioeconomy development, it is important to maintain holistic and systemic elements for analysis, i.e. how these measured phenomena interact, and what are the causal relationships. A novel approach in land and natural resource use science is to address the synergies and trade-offs of socio-economic activities. This concept would lead to the uptake of synergy and trade-off indicators that explain systemic patterns. These can be used to demonstrate the positive effects of the bioeconomy when compared to a fossil-based economy, but also help to avoid adverse effects and perverse incentives. Synergy and trade-off indicators can be designed to clearly demonstrate the positive and negative effects of action and policies. These indicators, and proper metrics, could monitor critical issues related to:

- land use competition and indirect land use effects (both EU and globally);

- the effects of intensified management and conservation:

- the relationship between biomass use and biodiversity;

- balance between material and energy use of biomass;

- the implications of increasing use of biomass on carbon sequestration;
- effects on urban and rural development;

- a holistic view of technological rationalisation and its social effects;

- effects on natural and social capital.

The indicators are deemed to help to safeguard sustainable bioeconomy development. They have the advantage of being easily communicated to stakeholders and the general public. However, it needs a broad consensus among policy makers as to which aspects to prioritise. This approach also needs to be consistent and accepted across European, national and regional scales, in particular where subsidiary policies are in place.

\subsection{How to develop indicators - a matter of smart design}

The development of indicators goes beyond a technical exercise and is much more than creating new and additional indicator lists. It is a non-trivial and highly political process involving actors from all parts of society and policy makers - a process in which a balance of needs and interests is required. The process of getting to an indicator set is equally important to the outcome, because beyond methodological soundness and applicability, it is also about 
the legitimacy and acceptance of indicators as key information tools. This is the reason why all the indicators proposed in this study should be seen as optional for further development, and not a pre-emption of participatory indicator processes.

In indicator processes, research has shown that the quality control of indicators under development is of prime importance. Quality considerations include conceptual issues (what to measure), technical facets (how to measure), and procedural aspects (whom to involve; who decides). Seven major principles for indicator development should be taken into account:

I. Relevance for sustainable development of the bioeconomy: indicators should provide relevant measures for the goal of sustainable development of the bioeconomy. This relevance may differ depending on the geographical scale at which they are applied.

2. Compatibility with existing sets: consistency with relevant existing indicator sets (sector-specific and general sustainability frameworks) with respect to themes and issues could enhance political relevance and acceptance.

3. Availability of data: indicators benefit from adequate data availability within the appropriate spatial scale, and should be based as far as possible on already existing, high quality and upto-date data. This would make use of existing competency in maintaining data sources and interpreting indicator values. A lack of data should be solved by the establishment of feasible data acquisition mechanisms.
4. Technical feasibility and scale: indicators should be selected according to their practical applicability on various geographical scales. The timeliness of data and comparability of timelines and trends need to be aligned with other statistical instruments.

5. Affordable cost of indicator application: the cost of data collection has to be taken into account when selecting indicators. It is important to avoid redundancies, double-reporting and fragmentation of data collection.

6. Clarity and communication: the comprehensibility of an indicator is very important if it is to be accepted by target groups. Information should be easily understandable, helpful, mathematically and clear.

7. Relevance for political decision-making and control: indicators should support political decision-making by providing evidence on sustainable development. The data should be easy to interpret and reveal trends in time in order to be able to point out successes or failures.

These principles give guidance for the further development of bioeconomy indicators. Principle 4 (technical feasibility) and 5 (costs of indicator application) were not applied in this study, as the focus was on topics and not on implementation.

Existing forest-related indicator processes and learning from related experiences provide a good basis for defining what to assess and how to monitor a forest bioeconomy value chain that broadens the understanding of the forest-based sector and creates links and synergies to other sectors. 


\section{Towards European bioeconomy monitoring: a synthesis}

At present, there is a fragmented landscape of bioeconomy-related data and monitoring instruments. Current indicators for the forest-based sector have - reasonably - focused very much on the resource side: forests and their management, and achieved considerable impact. However, to fully understand the implications of a forest-based bioeconomy, a broader approach is needed.

Bringing together data and key indicators will help understand and illustrate the current state of the forest-related bioeconomy, and identify future trends and provide foresight analysis. Some important aspects to consider are listed below.

\section{Reach beyond forest sector boundaries}

When policy objectives for the bioeconomy are set, significant gaps still exist in our capacity to monitor and assess their status and progress. Future forest-based bioeconomy monitoring needs to be broader and more diverse. There is a need to measure the entire forest value chains for solid wood products, wood-based materials and bioenergy production, fully accounting for woody biomass flows, trading, cascading and recycling needs. Broadening also means pushing the boundaries of the forest sector and its self-perception. It requires going beyond the traditional forest sector framework and moving towards diversified and cross-sectoral approaches.

This generates new challenges for data and monitoring. For example, currently the national statistics and EU statistics only monitor traditional forest sector economic activities (pulp, paper and wood products, and forestry related to these), and leave out bioenergy, chemicals, textiles, etc., that are based on forest biomass. As a result, the economic value-added and employment statistics lag behind the actual development we observe in the forest-based bioeconomy. Consequently, for economic and social indicators there is need to develop better data that helps to monitor and assess the increasing diversification of the forest-based sector.

Harmonise data acquisition and assessment Currently, data and indicators are clearly insufficient to provide a comprehensive view. While there is an overwhelming amount of data collected in the
$\mathrm{EU}$, only a limited proportion is ready for the assessment of impacts, progress and trends. Often, there are too many indicators which are contradictory or redundant. It has to be decided how the competences of EU Member States are formulated, ideally creating a joint agenda for bioeconomy monitoring. An EU monitoring instrument could push forward the harmonisation of data gathering, common definitions and a consistent means for interpretation, further stipulating and channelling methodological advancements.

Yet, a monitoring instrument should also acknowledge the large differences in Member States' forests and forest sectors. A one-size-fits-all monitoring system may not be optimal or possible, but rather the general EU-level monitoring principles need to be tailored to national and regional circumstances. There is also a need to invest resources to be able to get data, for example regarding forest-based bioenergy, chemicals, and the sector's economic and employment development. Currently, these do not exist.

\section{Build a flexible tool for future challenges}

Creating a new, integrated method of monitoring is not trivial. A way forwards could be continuous evolution: the harmonisation of existing indicator tools, leading to novel bioeconomy indicators in the future. However, this must be a flexible concept. It is not useful to develop static approaches which are outdated the moment they are applied. Forest bioeconomy monitoring has to be responsive to new global challenges, market developments, emerging trends and social and ecological risks. For example, recent trends in climate change, digitalisation of society or bioenergy indicate that there is a continuous need to update monitoring and indicator processes, and to integrate them into decision-making.

\section{Link to the political arena}

When designing a new bioeconomy monitoring instrument, it should be able to respond to new policy developments. It is imperative to identify synergies in data collection, reporting and synthesis of analyses, as well as to link to global initiatives to streamline assessments/reporting and to benchmark the 
EU in a global context. This is important with regard to post-2020 follow-ups of the EU Bioeconomy Strategy, the UN Agenda 2030 and the Sustainable Development Goals (SDGs), and also to reflect national needs when implementing bioeconomy strategies. It is important to balance national interests and EU competencies in monitoring efforts to create synergies and not opposition, and leave space for countries to develop their own ways towards forest bioeconomy based on their respective strengths and regional circumstances.

The absence of a common forest policy in the EU may limit the implementation of a forest-based bioeconomy indicator set. The effectiveness in implementing or adopting indicators may be affected by local regulations, laws and other restrictions as well. It is important to recognise different levels of policy implementation that make bioeconomy indicators multi-functional for national, European and international levels.

\section{Create a platform for joining forces}

An EU bioeconomy monitoring instrument is more than an inventory design or a database. Ideally, it has to serve as a platform for debate and negotiation; offer a knowledge base and provide mapping of knowledge gaps; and identify best practices, opportunities and recommendations to contribute information directly to the science-policy interface. The indicators used have the potential to span policy making at EU and Member State levels, to monitor at the business level, and hence create opportunities for different sectors to exchange along a commonly defined framework. Current initiatives such as the EU Bioeconomy Observatory and the Bioeconomy Knowledge Centre can act as a catalyst of indicator development and data quality, and connect relevant actors from science, business and national and EU policy. There is a need for increased collaboration of major research institutions and data providers, as well as participatory modes of interaction (EU, countries, public) that help to facilitate a broad consensus on the direction a forest-based bioeconomy should take. 


\section{Policy implications}

European forests and the forest-based sector play a central role in a bioeconomy: they provide material (wood and non-wood), bioenergy and a wealth of other regulating and cultural ecosystem services. These demands need to be properly balanced.

Bioeconomy indicators need to reflect the increasingly changing and diversifying European forest-based sector, and the impacts that these changes have on forest resources and forest-based products. A good lesson to remember is the impacts of the first generation biofuels boom in the beginning of this century, which caused problems e.g., in energy efficiency, $\mathrm{CO}_{2}$ impacts, land use and food prices. Indicators and assessment should help to avoid such unwanted impacts, and support successful and sustainable bioeconomy development.

- Indicators need to better capture the possible synergies and trade-offs between the different societal demands for forest resources, and between the forest sector and other sectors. They need to be responsive to new developments in the environment, society, and economy, and connect information on past and current states with prospective, forward-looking elements. Foresight and impact assessment tools are state-of-the-art methods that could be employed in a common bioeconomy indicator framework in this respect.

- Because of the diversification of the forest-based sector there is also a need to develop the collection and recording of the statistics that form the basis of the indicators, to more accurately reflect changes. Forest monitoring would benefit from being harmonised and its instruments made comparable with other sectoral instruments. The EU Bioeconomy Observatory/Bioeconomy Knowledge Centre initiatives could help to streamline data collection, assessment and interpretation of the impacts of the bioeconomy in the future.

- Forest-related policies are fragmented across sectors. The bioeconomy, as an umbrella concept, has the opportunity to raise forest-based issues to a new level, not segregated from other sectors' activities. Forest indicators are proven tools for monitoring the sustainability of forestry activities, but there is evidence that the sustainability impacts of forestry and forest products are not fully recognised outside the sector. The experience and lessons learned from forest indicator development and processes (e.g., FOREST EUROPE) should be made use of, and these indicators further updated and developed to fit the whole forest-based bioeconomy.

- Indicator development is often more a political than a technical task. Frequently, the strongest effort is put into technical design and data collection, while the negotiation of principles and goals is neglected. A cross-sectoral political forum could debate the priorities, metrics of assessment, choice of targets and the acceptance of trade-offs. With the EU Bioeconomy Panel and the European Bioeconomy Alliance there are already fora which enable cross-sectoral dialogue and cooperation.

- It is important to consider national strategies and approaches, and their role in the EU bioeconomy as a whole. Bioeconomy indicators have to feed into the discussion and planning of appropriate land use in Europe, the optimal use of our resources, and an awareness of possible leakage effects of European policies into the rest of the world (e.g., biomass imports). However, it should be acknowledged that EU Member States' forests and their forest sectors differ greatly, and a novel monitoring process should be a supporting instrument rather than an imperative.

- Indicators have so far been mainly used on a technical and administrational level. However, indicators could be used to communicate and provide information to the wider public, as well as supporting new forms of information-sharing and citizen science. New approaches such as key and headline indicators and indices should be tested to satisfy these needs.

- Indicators form the structural and methodological backbone of integrated bioeconomy monitoring. A common platform for the EU data providers and national data gatherers requires consensus and agreement on procedures, goals and targets. 


\section{Appendix}

Table 1. EU policies relating to forests and the forest-based sector.

\begin{tabular}{|c|c|c|c|}
\hline EU policies & $\begin{array}{l}\text { Main objectives of policies in } \\
\text { relation to forests }\end{array}$ & $\begin{array}{l}\text { Potential impact on forest re- } \\
\text { source (management, availabil- } \\
\text { ity and use) }\end{array}$ & $\begin{array}{l}\text { Potential impact on com- } \\
\text { petitiveness of forest-based } \\
\text { industry (costs) }\end{array}$ \\
\hline $\begin{array}{l}\text { Forest- } \\
\text { focused }\end{array}$ & $\begin{array}{l}\text { Multiple use of forests in } \\
\text { accordance with principles of } \\
\text { sustainable forest management }\end{array}$ & $\begin{array}{l}\text { Sustainable management of } \\
\text { forests }\end{array}$ & Potential positive impact \\
\hline Agricultural & $\begin{array}{l}\text { Focus on rural development } \\
\text { by also addressing forests and } \\
\text { agriculture including ecosys- } \\
\text { tem services }\end{array}$ & $\begin{array}{l}\text { Enhance rural development } \\
\text { and economic competitive- } \\
\text { ness of forest owners and e.g., } \\
\text { afforestation measures }\end{array}$ & Potential positive impact \\
\hline $\begin{array}{l}\text { Environ- } \\
\text { mental }\end{array}$ & $\begin{array}{l}\text { Nature and forest protection } \\
\text { including forest ecosystem } \\
\text { services }\end{array}$ & $\begin{array}{l}\text { Protect forest resources, } \\
\text { impacting on its availability as } \\
\text { well as enhancing ecosystem } \\
\text { services and biodiversity }\end{array}$ & $\begin{array}{l}\text { Potential constraints on re- } \\
\text { source (biomass) availability }\end{array}$ \\
\hline $\begin{array}{l}\text { Climate } \\
\text { change }\end{array}$ & $\begin{array}{l}\text { Combat global warming also } \\
\text { through enhancing forest sinks, } \\
\text { storage and substitution }\end{array}$ & $\begin{array}{l}\text { Enhancing capacity of forests } \\
\text { to preserve and capture } \mathrm{CO}_{2}\end{array}$ & $\begin{array}{l}\text { Potential constraints on re- } \\
\text { source (biomass) availability }\end{array}$ \\
\hline Energy & $\begin{array}{l}\text { To increase share of renewable } \\
\text { energy and energy efficiency } \\
\text { through use of forest biomass }\end{array}$ & $\begin{array}{l}\text { Producing renewable energy } \\
\text { from woody biomass but also } \\
\text { reducing risk of indirect land } \\
\text { use change through biofuels }\end{array}$ & $\begin{array}{l}\text { Potential constraints through } \\
\text { increased forest biomass use } \\
\text { as an alternative source of } \\
\text { energy }\end{array}$ \\
\hline Transport & $\begin{array}{l}\text { Ensure road safety and regulate } \\
\text { sulphur emissions from ships }\end{array}$ & & $\begin{array}{l}\text { Potential constraints through } \\
\text { the need for investment in vehi- } \\
\text { cles and an increase in vessel } \\
\text { operating costs }\end{array}$ \\
\hline $\begin{array}{l}\text { Employ- } \\
\text { ment }\end{array}$ & $\begin{array}{l}\text { Protect workers' health and } \\
\text { safety }\end{array}$ & $\begin{array}{l}\text { Need to invest in occupational } \\
\text { safety and health measures }\end{array}$ & $\begin{array}{l}\text { Potential constraints through } \\
\text { the need to invest in occu- } \\
\text { pational safety and health } \\
\text { measures }\end{array}$ \\
\hline $\begin{array}{l}\text { Anti- } \\
\text { pollution }\end{array}$ & $\begin{array}{l}\text { Minimise pollution from indus- } \\
\text { trial activities to reduce emis- } \\
\text { sions to air, water and land }\end{array}$ & Safeguarding forest health & $\begin{array}{l}\text { Potential constraints through } \\
\text { enhancing environmental pro- } \\
\text { tection and reducing emissions } \\
\text { of pollutants as well as remedy- } \\
\text { ing environmental damage }\end{array}$ \\
\hline Product & $\begin{array}{l}\text { Ensure the safety of products } \\
\text { for sale (risk prevention) }\end{array}$ & & $\begin{array}{l}\text { Potential constraints arise from } \\
\text { the need to pay registration fees } \\
\text { for certain products, but also } \\
\text { include investments in assess- } \\
\text { ment systems }\end{array}$ \\
\hline $\begin{array}{l}\text { Competi- } \\
\text { tion }\end{array}$ & $\begin{array}{l}\text { Avoid distortions of competi- } \\
\text { tion and trade in the internal } \\
\text { market }\end{array}$ & & $\begin{array}{l}\text { Creates no or very little regu- } \\
\text { latory costs (since it aims at } \\
\text { avoiding distortions) }\end{array}$ \\
\hline $\begin{array}{l}\text { Construc- } \\
\text { tion }\end{array}$ & $\begin{array}{l}\text { Set out conditions for market- } \\
\text { ing construction products and } \\
\text { the use of CE (Declaration of } \\
\text { Conformity) marking }\end{array}$ & $\begin{array}{l}\text { Increased demand for high } \\
\text { quality timber }\end{array}$ & $\begin{array}{l}\text { Potential constraints arise from } \\
\text { the need to invest in assess- } \\
\text { ment systems }\end{array}$ \\
\hline Trade & $\begin{array}{l}\text { Stop the circulation of illegally } \\
\text { logged timber and timber } \\
\text { products }\end{array}$ & & $\begin{array}{l}\text { Potential constraints through } \\
\text { the necessity to prove the legal- } \\
\text { ity of timber and its products }\end{array}$ \\
\hline Waste & $\begin{array}{l}\text { Accept and manage waste after } \\
\text { usage }\end{array}$ & & $\begin{array}{l}\text { Potential constraints through } \\
\text { the need to invest in waste wa- } \\
\text { ter treatment, collection and re- } \\
\text { cycling of returned products and } \\
\text { waste, opportunities for cascade } \\
\text { use in a circular economy }\end{array}$ \\
\hline
\end{tabular}


Table 4. Potential forest-based indicator proposals for bioeconomy challenges.

Colour code for data availability/quality:

$\square$ OK $\quad \square$ under development or improving,

$\square$ limited $\square$ not available.

Key indicators are shown in bold.

\begin{tabular}{|c|c|c|c|}
\hline $\begin{array}{l}\text { Bioeconomy } \\
\text { criteria }\end{array}$ & Forest-related topics & Indicator proposals (Key indicators in bold) & $\begin{array}{l}\text { Data availa- } \\
\text { bility/quality }\end{array}$ \\
\hline \multirow{4}{*}{$\begin{array}{l}\text { 1) Ensuring food } \\
\text { security }\end{array}$} & \multirow{2}{*}{$\begin{array}{l}\text { Role of forests in watershed } \\
\text { management and the provi- } \\
\text { sion of water for agriculture } \\
\text { and fisheries to secure sus- } \\
\text { tainable food production }\end{array}$} & Blue water footprint & \\
\hline & & Water use in total FWC and by sub-sectors & \\
\hline & $\begin{array}{l}\text { Edible non-wood forest } \\
\text { products }\end{array}$ & $\begin{array}{l}\text { Value and quantity of marketed non-wood } \\
\text { goods from forest and other wooded land }\end{array}$ & \\
\hline & Forage and feed for livestock & $\mathrm{n} / \mathrm{a}$ & \\
\hline \multirow{24}{*}{$\begin{array}{l}\text { 2) Managing } \\
\text { natural resourc- } \\
\text { es sustainably }\end{array}$} & \multirow{16}{*}{$\begin{array}{l}\text { Present SFM criteria and } \\
\text { indicators for SFM }\end{array}$} & Natural resource index & \\
\hline & & Red List Index & \\
\hline & & Forest area & \\
\hline & & Forests under management plan & \\
\hline & & Protected forests & \\
\hline & & Threatened forest species & \\
\hline & & Age structure and/or diameter distribution & \\
\hline & & Increment and fellings & \\
\hline & & Roundwood & \\
\hline & & Growing stock & \\
\hline & & Forest fragmentation & \\
\hline & & Tree species composition & \\
\hline & & Regeneration & \\
\hline & & Naturalness & \\
\hline & & Deadwood & \\
\hline & & Common forest bird species & \\
\hline & Forest ecosystem services & $\begin{array}{l}\text { Value of marketed services on forest and other } \\
\text { wooded land }\end{array}$ & \\
\hline & \multirow{3}{*}{$\begin{array}{l}\text { Social services like health/ } \\
\text { wellbeing }\end{array}$} & Recreation in forests & \\
\hline & & Impacts on human wellbeing & \\
\hline & & Urban forestry and human health & \\
\hline & Desertification & Trends in forest land degradation & \\
\hline & \multirow[t]{2}{*}{ Illegal logging } & Illegal logging and associated trade & \\
\hline & & $\begin{array}{l}\text { Woody bioenergy feedstocks supplied in accord- } \\
\text { ance with EU Timber Regulation and FLEGT }\end{array}$ & \\
\hline & Green infrastructure & $\mathrm{n} / \mathrm{a}$ & \\
\hline
\end{tabular}


Table 4. Continued.

\begin{tabular}{|c|c|c|c|}
\hline $\begin{array}{l}\text { Bioeconomy } \\
\text { criteria }\end{array}$ & Forest-related topics & Indicator proposals (Key indicators in bold) & $\begin{array}{l}\text { Data availa- } \\
\text { bility/quality }\end{array}$ \\
\hline \multirow{17}{*}{$\begin{array}{l}\text { 3) Reducing } \\
\text { dependence on } \\
\text { non-renewable } \\
\text { resources }\end{array}$} & $\begin{array}{l}\text { Low carbon society: carbon } \\
\text { sequestration, carbon foot- } \\
\text { print, carbon neutrality }\end{array}$ & Carbon footprint & \\
\hline & \multirow{9}{*}{$\begin{array}{l}\text { Renewable goods: bio-based } \\
\text { products, bioenergy, carbon in } \\
\text { wood products }\end{array}$} & Resource productivity & \\
\hline & & Recycling rate for paper and wood products & \\
\hline & & Wood consumption & \\
\hline & & Raw material consumption & \\
\hline & & $\begin{array}{l}\text { Production of goods and services in total FWC } \\
\text { and by sub-sector }\end{array}$ & \\
\hline & & Use of wood in total FWC and by sub-sector & \\
\hline & & Cascading use of biomass & \\
\hline & & Use of permanent materials & \\
\hline & & Trade in wood & \\
\hline & Resource efficiency & \multirow{2}{*}{ Resource use of the bioeconomy } & \\
\hline & Biomass availability & & \\
\hline & \multirow[t]{4}{*}{$\begin{array}{l}\text { Energy security, independence } \\
\text { from non-renewables }\end{array}$} & $\begin{array}{l}\text { Share of renewable energy in gross final energy } \\
\text { consumption }\end{array}$ & \\
\hline & & $\begin{array}{l}\text { Cost-competitiveness of biofuels compared } \\
\text { with non-renewable energy sources }\end{array}$ & \\
\hline & & Net energy balance & \\
\hline & & Wood energy & \\
\hline & $\begin{array}{l}\text { Indirect land use change, } \\
\text { displacement effects of EU } \\
\text { biomass demand }\end{array}$ & $\begin{array}{l}\text { Indirect land use/embodied land for agricul- } \\
\text { ture and forestry products }\end{array}$ & \\
\hline \multirow{12}{*}{$\begin{array}{l}\text { 4) Mitigating } \\
\text { and adapting to } \\
\text { climate change }\end{array}$} & $\begin{array}{l}\text { Compliance with climate } \\
\text { protocol }\end{array}$ & Greenhouse gas balance & \\
\hline & Resource efficiency & Resource and materials efficiency & \\
\hline & Carbon accounting & Forest-related carbon stocks & \\
\hline & \multirow{4}{*}{$\begin{array}{l}\text { Climate change effects: dis- } \\
\text { eases, pests, fires }\end{array}$} & Forest damage & \\
\hline & & $\begin{array}{l}\text { Deposition and concentration of air pollutants } \\
\text { on forest and other wooded land }\end{array}$ & \\
\hline & & Defoliation & \\
\hline & & Soil condition & \\
\hline & \multirow[t]{5}{*}{ Resilience and risk } & Introduced tree species & \\
\hline & & Economic impacts of invasive species & \\
\hline & & Genetic resources & \\
\hline & & Genetically modified trees & \\
\hline & & Protective forests & \\
\hline
\end{tabular}


Table 4. Continued.

\begin{tabular}{|c|c|c|c|}
\hline $\begin{array}{l}\text { Bioeconomy } \\
\text { criteria }\end{array}$ & Forest-related topics & Indicator proposals (Key indicators in bold) & $\begin{array}{l}\text { Data availa- } \\
\text { bility/quality }\end{array}$ \\
\hline \multirow{20}{*}{$\begin{array}{l}\text { 5) Increasing } \\
\text { competitiveness } \\
\text { and creating } \\
\text { jobs }\end{array}$} & \multirow{2}{*}{$\begin{array}{l}\text { Jobs in rural and in urban } \\
\text { areas }\end{array}$} & Forest holdings & \\
\hline & & Contribution of forest sector to GDP & \\
\hline & \multirow[t]{4}{*}{ Forest sector workforce } & $\begin{array}{l}\text { Forest sector workforce (including outsourcing } \\
\text { of workforce and services) }\end{array}$ & \\
\hline & & $\begin{array}{l}\text { Education time in total FWC and training } \\
\text { expenditure as \% of turnover in total FWC }\end{array}$ & \\
\hline & & Quality of employment in total FWC & \\
\hline & & Occupational safety and health & \\
\hline & \multirow[t]{3}{*}{$\begin{array}{l}\text { Green jobs, services at the } \\
\text { outskirts of the sector }\end{array}$} & $\begin{array}{l}\text { Employment in the total bioeconomy and its } \\
\text { sectors, and the contribution of the bioecono- } \\
\text { my to total regional employment }\end{array}$ & \\
\hline & & $\begin{array}{l}\text { Production and employment in woodworking, } \\
\text { manufacture of pulp, paper and paper-board, } \\
\text { converting, printing }\end{array}$ & \\
\hline & & Renewable energy jobs & \\
\hline & \multirow[t]{8}{*}{ Innovation and start-ups } & Eco-innovation index & \\
\hline & & $\begin{array}{l}\text { Innovation - new products in total FWC and by } \\
\text { sub-sector }\end{array}$ & \\
\hline & & $\begin{array}{l}\text { Growth of specific bio-based technologies, } \\
\text { processes or products }\end{array}$ & \\
\hline & & $\begin{array}{l}\text { Use and development of biotechnology in the } \\
\text { bioeconomy }\end{array}$ & \\
\hline & & $\begin{array}{l}\text { Development of advanced biorefinery tech- } \\
\text { nologies for the production of energy and } \\
\text { materials }\end{array}$ & \\
\hline & & $\begin{array}{l}\text { Research into technical and organisational } \\
\text { aspects of new bioeconomy initiatives }\end{array}$ & \\
\hline & & $\begin{array}{l}\text { Development of environment-related technolo- } \\
\text { gies, \% all technologies }\end{array}$ & \\
\hline & & Patents on resource efficiency technologies & \\
\hline & $\begin{array}{l}\text { Diversification of forest-relat- } \\
\text { ed bio-based products }\end{array}$ & $\mathrm{n} / \mathrm{a}$ & \\
\hline & \multirow[t]{2}{*}{$\begin{array}{l}\text { Emerging societal trends and } \\
\text { new markets }\end{array}$} & $\begin{array}{l}\text { Share of biofuel industry that is part of the } \\
\text { bioeconomy in terms of GDP, employment, } \\
\text { turnover }\end{array}$ & \\
\hline & & $\begin{array}{l}\text { Share of chemical industry that is part of the } \\
\text { bioeconomy in terms of GDP, employment, } \\
\text { turnover }\end{array}$ & \\
\hline
\end{tabular}


Indicator type and what kind of information they capture

Out of a multitude of indicator typologies, the following were deemed most practical for analysis:

- Input indicators measure quantity, quality and the timeliness of resources provided for an activity (human, financial and material, technological and information).

- Activity indicators measure performed action, work or management interventions through which inputs are mobilised. Activity indicators should address the 'who', 'what' and 'where' of an activity.

- Output indicators measure quantity, quality and the timeliness of the products, goods and services that are the result of an economic activity. When combined with activity and input indicators, output indicators can provide measures of efficiency.

- Outcome indicators measure more general results generated by outputs of economic activities. Outcome indicators describe the real world changes that outputs produce.

- Process indicators refer to the compliance with agreed and standard procedures to pursue sustainable development that affects outputs or system states. They relate to actions that can be taken to improve the performance of these indicators, which in turn should improve the performance of the system output.

- Driving force indicators: The structure and characteristics of the socio-economic system, its economic processing, and household consumption patterns are considered driving forces (drivers), which are strongly shaped by the cultural, political, and economic context they are embedded in.
- Pressure indicators: Resource use and management activities put pressure on and potentially change the natural system, its ecosystems and ecosystem services and thus the underlying natural state.

- State indicators measure the quantity and quality of stocks in the socio-ecological system; or provide context and background information on a socio-ecological and socio-economic system that helps to explain the environment of bioeconomy activities.

- Impact indicators measure changes in the physical, chemical or biological state of the socio-ecological system and/or changes in outputs caused by exogenous drivers, and are most likely to have a direct influence on the outcomes of activities. Effects of pressures on the natural system are considered environmental impacts.

- Response indicators measure decisions and choices made within the system by individuals or by policy makers, as a response to changes in the societal as well as natural systems, with the aim to adapt to these.

- Assessment indicators are suitable for assessing the sustainability of the forest-related bioeconomy in a country, given that threshold or warning levels and time-series data are available.

- Trade-off indicators set two or more variables in direct relation to explain the consequences of strategies and activities. They can be seen as systemic impact indicators. 


\section{Abbreviations}

C\&I: Criteria and Indicators

FAO: Food and Agriculture Organisation of the United Nations

FRA: FAO Forest Resource Assessment

FSC: Forest Stewardship Council

FWC: Forestry Wood Chain

GDP: Gross Domestic Product

ITTO: International Tropical Timber Organisation

LULUCF: Land use, land-use change and forestry

OECD: Organisation for Economic Co-operation and Development

PEFC: Programme for the Endorsement of Forest Certification Schemes

SFM: Sustainable Forest Management

SDG: Sustainable Development Goal

UNECE: United Nations Economic Commission for Europe 


\section{Recommended reading}

Baycheva-Merger, T. and Wolfslehner, B. 2016. Evaluating the implementation of the Pan-European Criteria and Indicators for Sustainable Forest Management - A SWOT analysis. Ecological Indicators 60: II92II99. https://doi.org/ı0.10I6/j.ecolind.2015.09.009

Buytaert, V., Muys, B., Devriendt, N., Pelkmans, L., Kretzschmar, J. and Samson, R. 20Iı. Towards integrated sustainability assessment for energetic use of biomass: a state of the art evaluation of assessment tools. Renewable and Sustainable Energy Reviews 15: 3918-3933. https://oi.org/ı0.1016/j.rser.2011.07.036

Carus, M. Dammer, L. and Essel, R. 20I5. Options for Designing the Political Framework of the European Biobased Economy. Nova paper \#6 on bio-based economy.

European Forest Institute, 2013. Implementing Criteria and Indicators for Sustainable Forest Management in Europe. I32 p. ISBN: 978-952-5980-04-2.

FOREST EUROPE, 20I5. Meeting the Goals for European Forests and the European 2020 Targets for Forests. Report on the Mid-Term Evaluation of the Goals for European Forests and the European 2020 Targets for Forests, 47, 7th Ministerial Conference on the Protection of Forests in Europe. Forest Europe Liaison Unit Madrid, Madrid.

Gough, A.D., Innes, J.L. and Allen, S.D. 2008. Development of common indicators of sustainable forest management. Ecological Indicators 8: 425-430. https://doi.org/I0.IoI6/j.ecolind.2007.03.00I

Grainger, A. 20I2. Forest sustainability indicator systems as procedural policy tools in global environmental governance. Global Environmental Change 22 (I): I47-I60. https://doi.org/I0.I0I6/j.gloenvcha.20II.09.00I

Holvoet, B. and Muys, B. 2004. Sustainable forest management worldwide: a comparative assessment of standards. International Forestry Review 6(2): 99-I22. https://doi.org/I0.I505/ifor.6.2.99.38388

McCool, S.F. and Stankey, G.H. 2004. Indicators of sustainability: Challenges and opportunities at the interface of science and policy. Environmental Management 33: 294-305. https://doi.org/10.1007/s00267-003-0084-4

Pülzl, H. and Rametsteiner, E. 2009. Indicator development as 'boundary spanning' between scientists and policy makers. Science and Public Policy 36(Iо): 743-752. https://doi.org/I0.3152/030234209x481987

Rametsteiner, E., Pülzl, H. Alkan-Olsson, J. and Frederiksen P. 2oıı. Sustainability indicator development - science or political negotiation? Ecological Indicators II: 6I-70. https://doi.org/I0.I0I6/j.ecolind.2009.06.009

Robledo-Abad, C., Althaus, H.J., Berndes, G., Bolwig, S., Corbera, E., Creutzig, F., Garcia-Ulloa, J., Geddes, A., Gregg, J.S, Haberl, H., Hanger, S., Harper, R.J., Hunsberger, C., Larsen, R.K., Lauk, C., Leitner, S., Lilliestam, J., Lotze-Campen, H., Muys, B., Nordborg, M., Ölund, M., Orlowsky, B., Popp, A., Portugal-Pereira, J., Reinhard, J., Scheiffle, L. and Smith, P. 20I6. Bioenergy production and sustainable development: science base for policymaking remains limited. Global Change Biology Bioenergy. https://doi.org/Io.IIII/gcbb.I2338

Van Cauwenbergh, N., Biala, K., Bielders, C., Brouckaert, V., Franchois, L., Garcia Cidad, V., Hermy, M., Mathijs, E., Muys, B., Reijnders, J., Sauvenier, X., Valckx, J., Vanclooster, M., Van der Veken, B., Wauters, E. and Peeters, A. 2007. SAFE - a hierarchical framework for assessing the sustainability of agricultural systems. Agriculture, Ecosystems and Environment I20: 229-242. https://doi.org/ı0.1016/j.agee.2006.09.006

Wijewardana, D. 2008. Criteria and indicators for sustainable forest management: the road travelled and the way ahead. Ecological Indicators 8, II5-I22. https://doi.org/Io.IoI6/j.ecolind.2006.II.003 


\section{AUTHORS}

Bernhard Wolfslehner is Head of the EFI Central-East and South-East European Regional Office (EFICEEC-EFISEE), University of Natural Resources and Life Sciences, Vienna.

Stefanie Linser is a Senior Researcher at EFICEEC-EFISEE, University of Natural Resources and Life Sciences, Vienna.

Helga Pülzl is a Senior Researcher at EFICEEC-EFISEE, University of Natural Resources and Life Sciences, Vienna.

Annemarie Bastrup-Birk is Project Manager Forest and Environment at the European Environment Agency.

Andrea Camia is Scientific/Technical Projects Manager at the European Commission's Joint Research Centre, ISPRA, Italy.

Marco Marchetti is a Professor and Chair of Forest Management and Conservation at the University of Molise, Italy.

\section{ACKNOWLEDGEMENTS}

The report is based to a large extent on a synthesis of published documents and peer-reviewed studies. The manuscript's synthesis and implications drawn from these studies, however, received constructive comments and suggestions from the following external reviewers: Uwe R. Fritsche (IINAS - International Institute for Sustainability Analysis and Strategy) and Bart Muys (University of Leuven). We wish to thank them for their valuable comments and insights.

We express our warm thanks to our expert adviser Marilise Wolf-Crowther (Eurostat, Unit E2 Environmental statistics and accounts; sustainable development) for her significant help and comments throughout the whole report process. 

e are living in a time of accelerated changes and unprece-
dented global challenges: energy security, natural resource scarcity, biodiversity loss, fossil-resource dependence and climate change. Yet the challenges also demand new solutions and offer new opportunities. The cross-cutting nature of forests and the forest-based sector provides a strong basis to address these interconnected societal challenges, while supporting the development of a European bioeconomy.

The European Forest Institute is an unbiased, science-based international organisation that provides the best forest science knowledge and information for better informed policy making. EFI provides support for decision-takers, policy makers and institutions, bringing together cross-boundary scientific knowledge and expertise to strengthen science-policy dialogue.

This work and publication has been financed by EFl's MultiDonor Trust Fund for policy support, which is supported by the Governments of Austria, Finland, France, Germany, Ireland, Italy, Norway, Spain and Sweden.

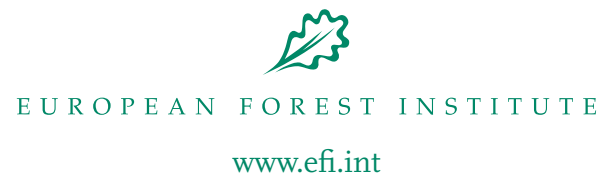

